Archives of Agriculture and Environmental Science

\title{
Phytoplankton and epipelic algal abundance in relation to bridge construction on Okpoka River in the Upper Bonny Estuary, Nigeria
}

\author{
Ihuoma Ejiowhor ${ }^{1}$, Miebaka Moslen ${ }^{2 *}$ (D) and Erema Ransome Daka ${ }^{3}$ \\ ${ }^{1,2}$ Department of Animal and Environmental Biology, Rivers State University, Port Harcourt, NIGERIA \\ ${ }^{3}$ Institute of Pollution Studies, Rivers State University, Port Harcourt, NIGERIA \\ *Corresponding author's E-mail:moslen4c@yahoo.com
}

\section{ARTICLE HISTORY}

Received: 12 November 2018

Revised received: 21 November 2018

Accepted: 24 November 2018

\section{Keywords}

Bonny estuary

Bridge construction

Epipelic algae

Okpoka River

Phytoplankton

\section{ABSTRACT}

The objective of this study was to determine the impact of bridge construction on abundance and composition of phytoplankton and epipelic algae with respect to bridge construction on a section (ATC Okrika Axis) of Okpoka River, upper Bonny estuary in Nigeria. Phytoplankton and epipelic algae were collected in five replicates from six stations (UA - upstream, BA bridge position, DA - downstream of bridge (reclaimed side) and (UC - upstream, BC - bridge position, DC downstream of bridge (vegetated side -mangrove) side of the river between January and March 2017. Thirty samples were collected per month with appropriate containers, preserved in $5 \%$ formalin-water mixture, taken to the laboratory and identified to the lowest possible taxonomic level. Ten species of phytoplankton (Gyrosigma spp., Synedra spp., Navicula spp., Nitzschia spp., Thalassiothrix spp., Coscinodiscus spp., Fragillaria spp., Pleurosigma spp., Cyclotella spp. and Rhizosolenia spp.) all belonging to the Baccillariophyceae (diatoms) were observed. Ten species (Gyrosigma spp., Navicula spp., Synedra spp., Nitzschia spp., Thalassiothrix spp., Coscinodiscus spp., Fragillaria spp., Pleurosigma spp., Cymbella spp. and Cocconeis spp.) of epipelic algae were also observed with the last two species in each group accounting for their differences. Cyclotella and Rhizosolema spp. were observed only on phytoplankton sampled and Cymbella and Cocconeis spp. were observed in epipelic algal samples suggesting minimal differences in composition. Analysis of variance indicated significant difference $(P<0.05)$ in the abundance of both phytoplankton and epipelic algae between stations close to bridge construction compared to others sites farther away. The study therefore, concluded that activities of bridge construction across the Okpoka River impacted on the abundance and composition of phytoplankton and epipelic within the study area. Regular monitoring is recommended particularly after construction in order to detect recovery changes of these important aquatic algae that form the base of the food chain.

(C)2018 Agriculture and Environmental Science Academy

Citation of this article: Ejiowhor, I., Moslen, M. and Daka, E.R. (2018). Phytoplankton and epipelic algal abundance in relation to bridge construction on Okpoka River in the Upper Bonny Estuary, Nigeria. Archives of Agriculture and Environmental Science, 3(4): 337-343, https://dx.doi.org/10.26832/24566632.2018.030402

\section{INTRODUCTION}

Bridge construction activities can have adverse impacts on water quality (Hedrick et al., 2010). These adverse impacts resulting from disruptions of ecosystem processes may take years to fully manifest themselves (Jackson, 2003). Phytoplanktons are single celled organisms which are the grasses of the sea and play a very vital role in the sea to form the basis of ocean productivity. Some of these phytoplankton but not all are in turn grazed on by zooplankton which is dominated by small crustaceans such as copepods, shrimps and their larvae (Portner and Farell, 2008). Bridge construction has the potential to disturb ecosystems through a variety of pathways (Sagar et al., 2004; Hedrick et al., 2010); differential sensitivities will lead to ecological winners and losers. Also a temporal and spatial shift in relationship between species e.g. shifts in terms of 
phytoplankton and epipelic algae abundance relative to food availability in water (Giberto et al., 2004; Farkas et al., 2001). These may also lead to changes in nutrient cycling. There are evidence that indicates bridge construction to block the passage of fishes in water (Ruediger, 2001; Roni et al., 2002). The amount of phytoplankton in water column reflects the influence of a number of environmental factors and processes.

Epipelic algae are free living on submerged sediment (Rennie and Jackson, 2005). Epipelic algae serve as available food base for many invertebrates and waterfowl (Kara and Sahin, 2000). About $70 \%$ of the invertebrate production was supported by attached algae (Borowitzka et al., 1990). Phytoplankton and Epipelic algae are regarded as excellent indicators of environmental conditions of water habitats (Angermeier and Rosenberger 2005; Traunspurger and Drew, 1996; Harding et al., 2002) and have been introduced for biomonitoring studies. The Okpoka creek is dominated by Nypa palm (Nypa fruticans), Red mangrove (Rhizophora racemosa), white mangrove (Avicennia nitida) and other species of water ferns.

Development projects such as bridge construction could impact on the ecology of aquatic systems; hence the aim of this study is to assess the effect of anthropogenic activity on the abundance and composition of algae on a section of the Okpoka River in the Upper Bonny Estuary, Nigeria. This shall enable distinction in composition and abundance between phytoplankton (water column) and epipelic algae (surface sediment) in relation to a specific activity that impacts on them simultaneously.

\section{MATERIALS AND METHODS}

\section{Study site}

The study site is a section (ATC Okrika Axis) of the Okpoka River and a major bridge construction is on-going in the Okpoka Creek. The coordinates of the sampled sites are (BA: $\mathrm{E} 007^{\circ} 04^{\prime}$ 36.1, N $04^{\circ} 44^{\prime} 22$; BC: $\mathrm{E} 007^{0} 04^{\prime}$ 27.3, N 04. 44. 22.06; DA: E $007^{\circ} 04^{\prime}$ 37.2, N $04^{\circ} 44^{\prime}$ 17.6; DC: E $007^{0} 04^{\prime} 25.3$, N $04^{0} 44^{\prime}$ 18.5; UA: E $007^{0} 04^{\prime} 35.3$, N $04^{0} 4^{\prime} 4^{\prime} 28.0$; E $007^{0} 04^{\prime} 37.2, \mathrm{~N}^{\circ} 4^{0}$
44 24.0). It is a tidal river that supports major economic activities like fishing and marine transportation. Development needs has attracted a bridge construction project and recently oil bunkering activities has been observed in the area. One side of the river still has mangrove vegetation while the other side had been reclaimed for expansion of residential area. Vegetations on one side include Nypa palm (Nypa fruticans), white mangrove (Avicennia nitida) red mangrove (Rhozophora racemosa) and other water ferns. Domestic wastes dumps were also observed on the bank of the residential side of the river. Figure 1 shows study location and sampled points. UA, BA, DA represented upstream, bridge position and downstream on the reclaimed side of the while UC, BC, DC has the same positions but on the vegetated (mangrove vegetation) side of the river.

\section{Sample collection and analysis}

Five replicates samples were collected randomly from each station for six stations making a total of ninety samples at monthly intervals for three (3) months (January to March 2017). Sediment samples were collected with an Ekman grab $(15 \mathrm{~cm} \times$ $15 \mathrm{~cm}$ ) and epipelic algae carefully scraped from the surface of sediments into sterile bottles. Samples were preserved in 5\% formalin-sea water mixture and immediately taken to the laboratory for analysis. Epipelic algae were analyzed according to Ogamba (2003; Wickstead, 1976).

Phytoplankton samples were collected directly with one liter contain open mouth containers and also preserved in 5\% formalin and taken to the laboratory for analysis. The preserved phytoplankton samples (APHA, 2012) was allowed to stand for at least a minimum of 24 hours in the laboratory before decanting the supernatant. The decanting was done carefully until a $50 \mathrm{ml}$ concentration sample was left. The concentrated sample containing the organism (phytoplankton) was thoroughly shaken and a one $\mathrm{ml}(1 \mathrm{ml}$ ) of sub-sample was collected using a stamped pipette into a Bogoros counting chamber (Wickstead, 1976), identification and enumeration was carried out under a light microscope.

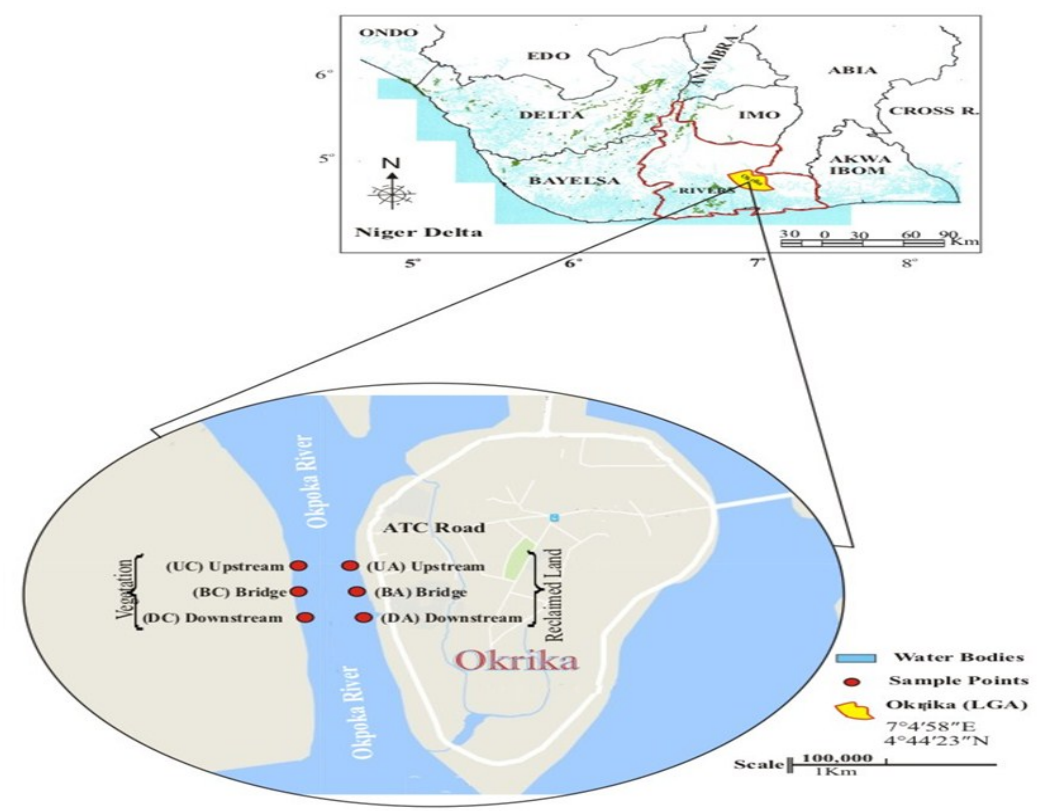

Figure 1. Study location showing sampled sites at Okpoka River in the Upper Bonny Estuary, Nigeria. 


\section{Statistical analysis}

The software package MINITAB was used for analysis of variance in terms of the abundance of organisms with respect to the stations examined. This was important in order to detect statistically significant variations in organism abundance across the stations sampled.

\section{RESULTS AND DISCUSSION}

Composition and abundance of phytoplankton

Table 1 presents checklist of phytoplankton observed during the study while Figure 2 presents the variations in density of organisms ( \pm standard error bars) across the stations examined. Phytoplankton composition and abundance across all stations (UA, UC, BA, BC, DA, and DC) had only the Bacillariophyceae with ten species (Gyrosigma spp., Synedra spp., Navicula spp., Nitzschia spp., Coscinodicus spp., Cyclotella spp., Pleurosigma spp., Thalassiothrix spp., Fragillaria spp., Rhizosolenia spp.). Six of this species (Gyrosigma spp., Synedra spp., Navicula spp, Nitzschia spp., Coscinodicus spp. and Thalassiothrix spp.) were observed in all the stations (UA,UC,BA,BC,DA,DC) while Cyclotella spp and Rhzosolenia spp. were obtained only at Station (BC). Gyrosigma spp. were obtained in all stations with density ranging from $16-$ 190 cells/ml with the lowest and highest observed at (UC) and DC, respectively. Synedra spp. were also observed in all stations with density values in the range of $10-111$ cells $/ \mathrm{ml}$ with the highest seen at station UC and the lowest at station DA. Navicula spp. also observed in all stations had most density (221 cells/ $\mathrm{ml}$ ) at station DC and least density ( 7 cells $/ \mathrm{ml}$ ) at station UC. The highest density of Thalassiothrix spp. (22 cells/ml) was obtained at station UC and the least ( 2 cells $/ \mathrm{ml}$ ) was recorded at station BC. Cyclotella spp. was recorded only in stations UA, DA and DC with density ranging from $3-19$ cells $/ \mathrm{ml}$. The highest (19 cells/ $\mathrm{ml}$ ) values was obtained at station UA and the least (3 cells/ $\mathrm{ml}$ ) values was noticed at stations DA and DC. Coscinodicus spp. was obtained in all the Stations with the highest $(109 \mathrm{cells} / \mathrm{ml})$ density obtained at station BA and the least $(10$ cells $/ \mathrm{ml})$ at Station UC. However, Pleurosigma spp. were seen in only three stations (UC,BA and,DA) with the highest ( 16 cells $/ \mathrm{ml}$ ) at station DA and the least ( 1 cell $/ \mathrm{ml}$ ) obtained at station UC. Fragillaria spp. were obtained in stations UA, UC, BA ,BC and ,DA but

Table 1. Check list of phytoplankton observed in Okpoka River in the Upper Bonny Estuary, Nigeria.

\begin{tabular}{|c|c|c|c|c|c|c|}
\hline \multirow{2}{*}{ Species } & \multicolumn{6}{|c|}{ Stations } \\
\hline & UA & UC & BA & BC & DA & $\mathrm{DC}$ \\
\hline Gyrosigma spp. & + & + & + & + & + & + \\
\hline Synedra spp. & + & + & + & + & + & + \\
\hline Coscinodicus spp. & + & + & + & + & + & + \\
\hline Cyclotella spp. & - & - & _ & + & _ & - \\
\hline Navicula spp. & + & + & + & + & + & + \\
\hline Nitzschia spp. & + & + & + & + & + & + \\
\hline Fragilaria spp. & + & - & + & + & + & + \\
\hline Rhizosolenia spp. & - & - & - & + & - & - \\
\hline Thalassiothrix spp. & + & + & + & + & + & + \\
\hline Pleurosigma spp. & + & + & - & + & + & + \\
\hline
\end{tabular}

was not found in station DC. Cell density range from 7 - 28 cells $/ \mathrm{ml}$ with the highest $(28$ cells $/ \mathrm{ml}$ ) recorded at station UA and the least (7cells $/ \mathrm{ml}$ ) reported at station $\mathrm{BC}$.

\section{Abundance and composition of epipelic algae}

Table 2 presents a checklist of epipelic algae observed during the study while Figure 3 presents the density of organisms with standard error bars across the stations examined. The Bacillariophyceae were also the only epipelic algae observed in all stations during the study. The abundance of the epipelic algae were generally more than the phytoplankton. Gyrosigma spp. were obtained in all Stations (UA,UC, BA, BC, DA, DC) with number of cells per $\mathrm{ml}$ ranging from $500-1230$ Cells $/ \mathrm{ml}$ at stations BA and UC respectively while Cocconeis spp. was noticed only at one station with a density of 0.2 cells $/ \mathrm{ml}$. Cymbella spp. was observed only at two stations (DA and DC) with not more than 5 cell/ml but Pleurosigma spp. were obtained in all stations with value ranges of $61-1267 \mathrm{cells} / \mathrm{ml}$ at stations UC and UA respectively. Thalassiothrix spp. were observed at 5 Stations (UA, BA, BC, DA , DC) with density values that range from 0 - 107 cells $/ \mathrm{ml}$.The highest $(107 \mathrm{cells} / \mathrm{ml})$ was obtained at station UA and the lowest ( 0 cell $/ \mathrm{ml}$ ) was noticed at station UC. Navicula spp and Nitzschia spp. were recorded in all stations with density ranges of $125-5301$ cells/ml at stations UC and DC and 117 - 357 cells/ml at stations UC and DA, respectively.

Analysis of variance indicated that there was significant difference in the abundance of phytoplankton (Gyrosigma spp., Navicula spp., Nitzschia spp., Coscinodiscus spp. Cyclotella spp. Pleurosigma spp.) as well as epipelic alagae (Synedra spp., Navicula spp., Nitzschia spp., Coscinodiscus spp., Pleurosigma spp., Thalassiothrix spp., Fragillaria spp.) across the stations examined. Such difference was attributed to the impact of the bridge construction activities in relation to other stations farther away from the bridge area.

Comparison of phytoplankton and epipelic algae species indicated that eight species (Gyrosigma spp., Synedra spp., Navicula spp., Nitzschia spp., Coscinodicus spp., Pleurosigma spp., Thalassiothrix spp., Fragillaria spp.,) were common to both groups whereas two species Cyclotella spp. and Rhizosolema spp. were only present in the phytoplankton and Cymbella spp. and Cocconeis spp. were observed only in Epipelic algae.

Table 2. Check list of epipelic algae observed in Okpoka River in the Upper Bonny Estuary, Nigeria.

\begin{tabular}{lcccccc}
\hline \multirow{2}{*}{ Species } & \multicolumn{7}{c}{ Stations } \\
\cline { 2 - 7 } & UA & UC & BA & BC & DA & DC \\
\hline Gyrosigma spp. & + & + & + & + & + & + \\
Synedra spp. & + & + & + & + & + & + \\
Coscinodicus spp. & + & + & + & + & + & + \\
Cymbella spp. & - & - & - & - & + & - \\
Navicula spp. & + & + & + & + & + & + \\
Nitzschia spp. & + & + & + & + & + & + \\
Fragilaria spp. & - & + & + & - & + & + \\
Cocconeis spp. & - & - & - & - & + & - \\
Thalassiothrix spp. & + & + & + & + & + & + \\
Pleurosigma spp. & + & + & + & + & + & + \\
\hline
\end{tabular}


Table 3. Composition of phytoplankton and epipelic algae and $p$-value of analysis of variance.

\begin{tabular}{lcccc}
\hline Species & Phytoplankton & Epipelic algae & p-value (phytoplankton) & p-value (Epipelic Alagae) \\
\hline Gyrosigma & + & + & $0.01^{*}$ & 0.11 \\
Synedra & + & + & 0.69 & $0.01^{*}$ \\
Navicula & + & + & $0.01^{*}$ & $0.01^{*}$ \\
Nitzschia & + & + & $0.01^{*}$ & $0.01^{*}$ \\
Coscinodiscus & + & + & $0.01^{*}$ & $0.01^{*}$ \\
Cyclotella & + & - & $0.01^{*}$ & - \\
Pleurosigma & + & + & $0.01^{*}$ & $0.01^{*}$ \\
Thalassiothrix & + & + & 0.06 & $0.04^{*}$ \\
Fragillaria & + & + & 0.15 & $0.01^{*}$ \\
Rhizosolema & + & - & 0.53 & - \\
Cymbella & - & + & - & 0.36 \\
Cocconeis & - & + & - & 0.43 \\
\hline
\end{tabular}

Key: ${ }^{*}$ Significant difference $(P<0.05)$

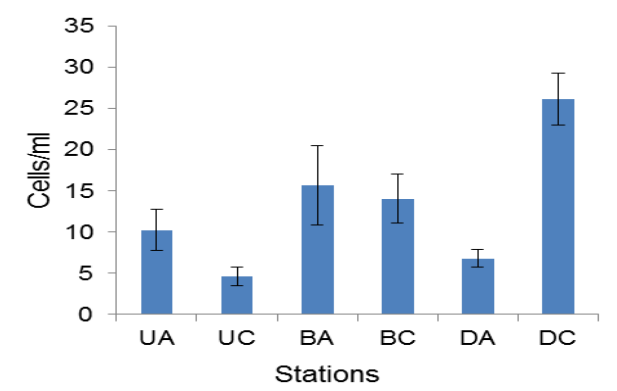

(A) Gyrosigma spp.

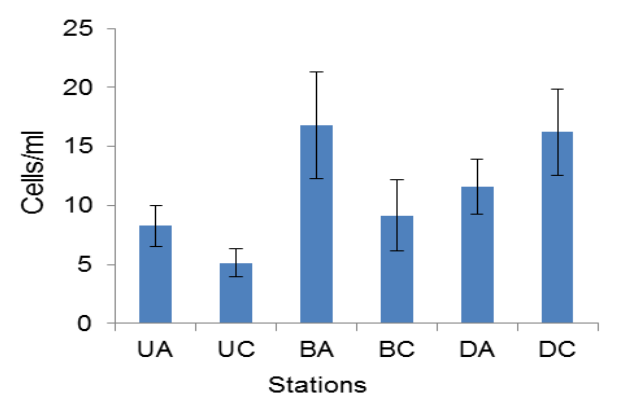

(D) Coscinodicus spp.

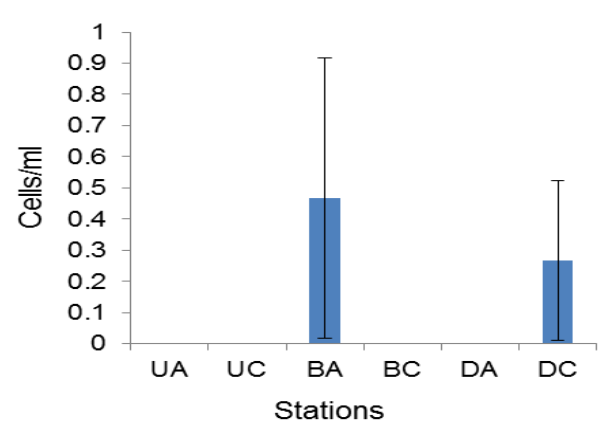

(G) Rhizosolema spp.

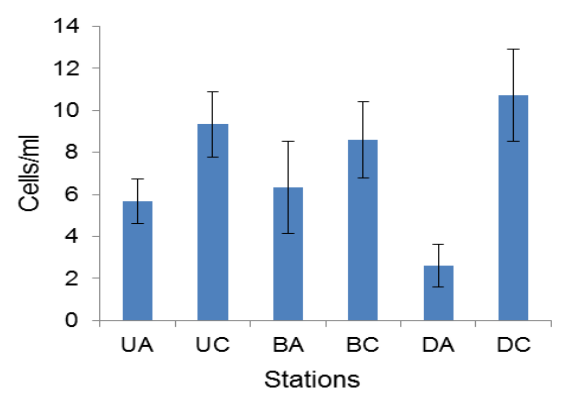

(B) Synedra spp.

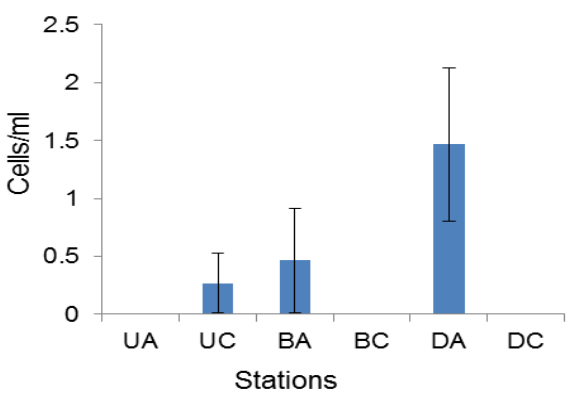

(E) Pleurosigma spp.

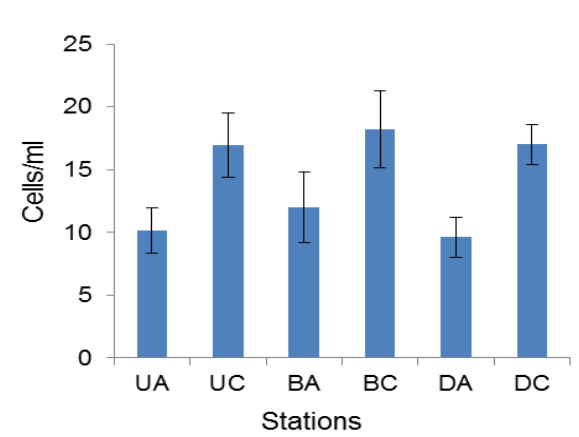

(H) Nitzschia spp.

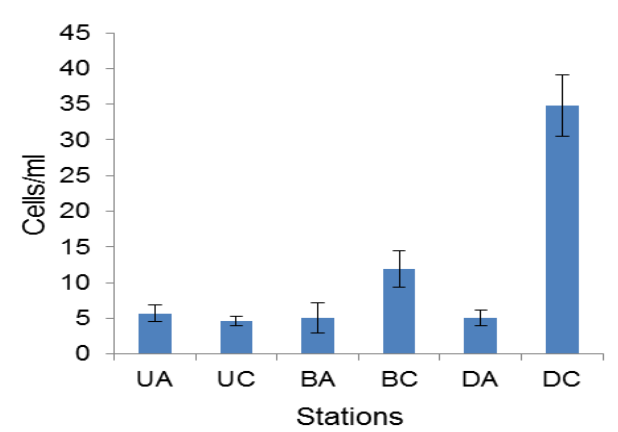

(J) Navicula spp.

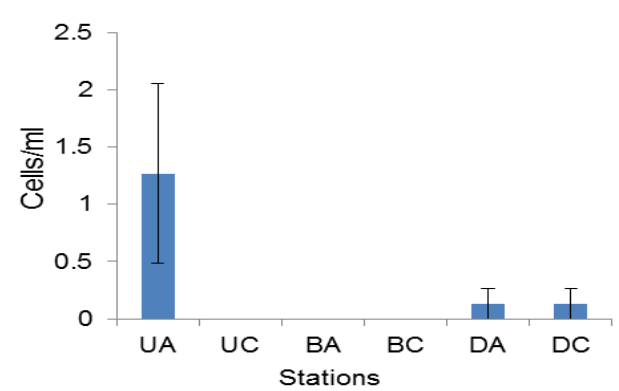

(C) Cyclotella spp.

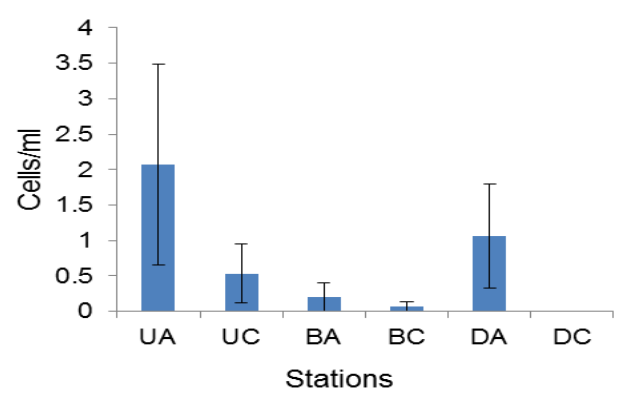

(F) Fragillaria spp.

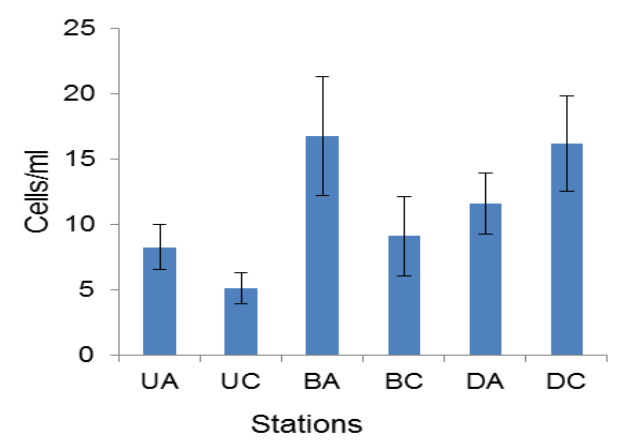

(I) Coscinodicus spp.

Figure 2 (A-J). Spatial variation in mean density of phytoplankton ( \pm Standard Error) across study sites at Okpoka River in the Upper Bonny Estuary, Nigeria. 
The predominance of Bacillariophyceae in Niger Delta waters is not only seen in Phytoplankton communities but also in Epipelic algal communities (Chindah and Nduaguibe, 2003; Nwankwo et al., 2003; Chindah, 2004). Species found were almost in all stations indicating a widespread occurrence of Bacillariophyceae in Okpoka River. Townsend et al. (1992a, 1994b), in his studies investigated that the dominance of Bacillariophyceae is a common feature of the open euthropic water systems. Irrespective of the environmental influence, the diatoms (Bacillariophyceae) dominated the entire community of phytoplankton and epipelic algae with Nitzchia spp., Coscinodiscus spp., Navicula spp., Synedra spp., Gyrosigma spp., Pleurosigma spp., Thalassiothrix spp. and Fragillaria spp. being the most abundant consequently, the distribution pattern for the stations differs in their diversity of numbers.

The community of phytoplankton and epipelic algae plays an important role as primary producers in aquatic ecosystems.
Their species have been extensively used as an indication of environmental change such as eutrophication, acidification, salinification (Polge et al., 2010). Low concentration of nutrients generally has significant implication for phytoplankton composition (Kadiri, 2000). The dominance of phytoplankton and epipelic algae in this study area is in agreement with research made by Nwadiaro (1990) in Canon creek system of the Niger Delta, Chindah and Pudo (1991) in Bonny River, Erondu and Chindah (1991) in the New Calabar River. The presence of elevated value of bacillariophyceae indicated bad quality of water (Verma, 2002) hence bacillariophyceae are regarded as a good indicator of water pollution (Prasad and Singh, 1996). According to the reports of Nair et al. (1981), Mishra et al. (2008), Manoj and Bhavesh (2008), Murugan (2008), that 8 elevated number of Nitzschia spp., Navicula spp., Fragilaria spp., Synedra spp,and Cocconeis spp. shows the presence of water pollutants.

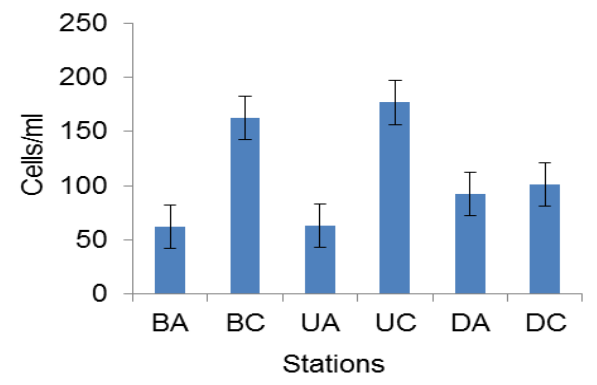

(A) Gyrosigma spp.

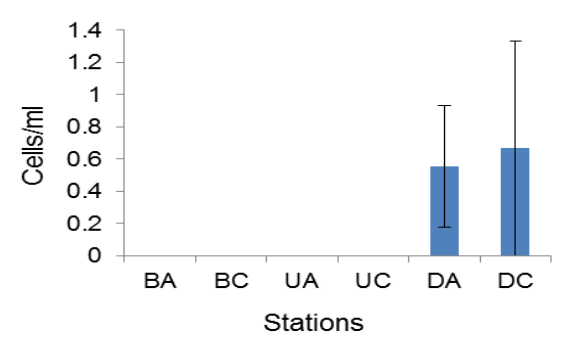

(D) Cymbella spp.

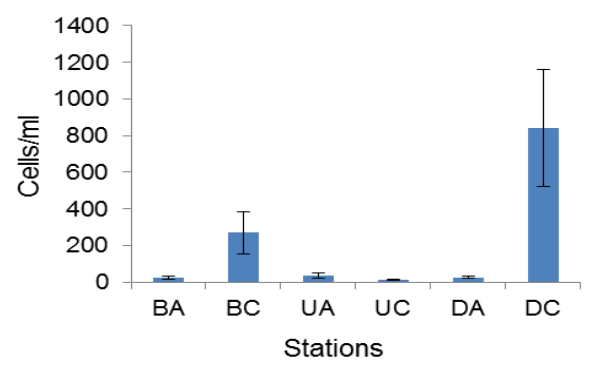

(G) Navicula spp.

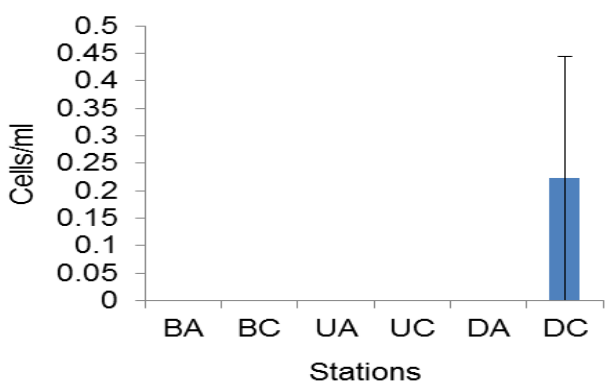

(B) Cocconeis spp.

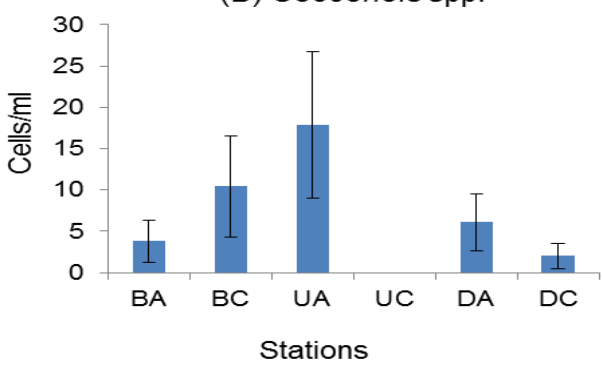

(E) Thalassiothrix spp.

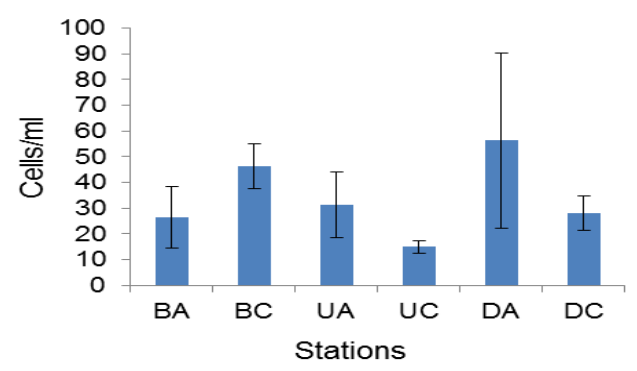

(H) Nitzschia spp.

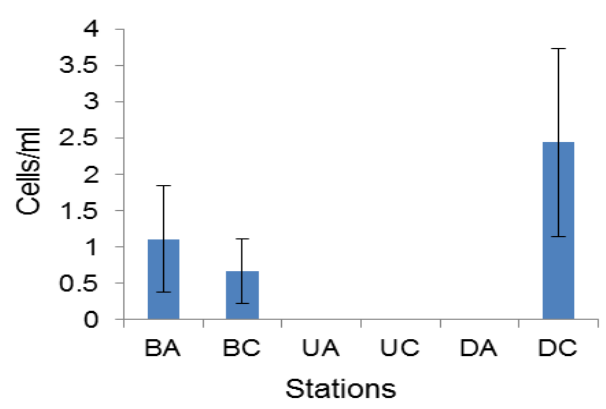

(J) Fragillaria spp.

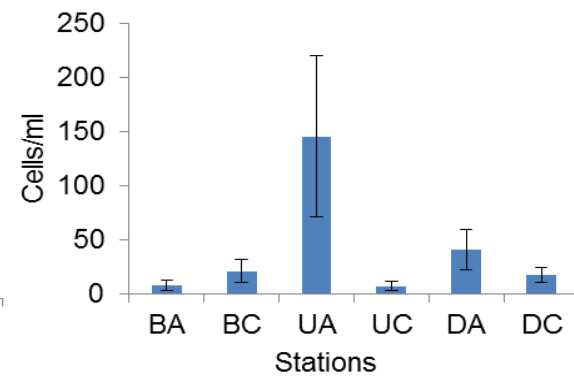

(C) Pleurosigma spp.

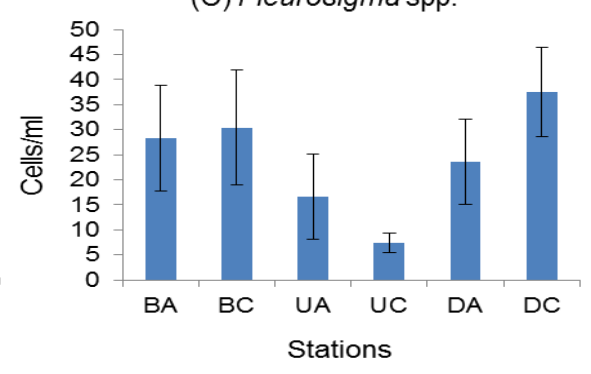

(F) Synedra spp.

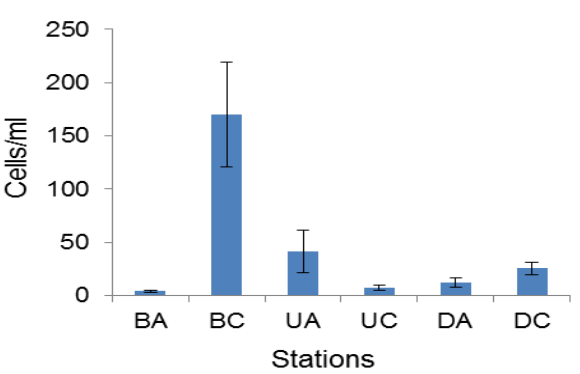

(I) Coscinodiscus spp.

Figure 3 (A-J). Density of organisms with standard error bars across the stations examined in Okpoka River in the Upper Bonny Estuary, Nigeria. 
Conclusion

Examination of the study are indicated the presence of phytoplankton and epipelic algae. This was however, singly dominated by the Bacillariophyceae in the water column and surface sediment. Common species of this family observed included Nitzchia spp., Coscinodiscus spp., Navicula spp., Synedra spp., Gyrosigma spp., Pleurosigma spp., Thalassiothrix spp. and Fragillaria spp. The density of phytoplankton (Gyrosigma spp.: 16 - 190 cells $/ \mathrm{ml}$; Synedra spp.: 10 - 111 cells/ml; Navicula spp.: 7 -221 cells/ml; Thalassiothrix spp.: 2 - 22 cells/ml; Cyclotella spp. 3 - 19 cells $/ \mathrm{ml}$; Coscinodicus spp. 10 - 109 cells/ml) observed during the study was generally less compared to the density of epipelic alagae (Gyrosigma spp.: 500 - 1230 Cells/ml; Cocconeis spp.: 0.2 cells/ ml; Cymbella spp. 0 - 5 cell/ml; Pleurosigma spp.: 61 - 1267 cells/ ml; Thalassiothrix spp.: 0 - 107 cells/ml; Navicula spp. 125 - 5301 cells/ml; Nitzschia spp.:117 - 357 cells/ml). Comparison of the result show higher abundance and composition of the phytoplankton and epipelic algae on the mangrove vegetation side of the study area thane the reclaimed side. Again, composition and abundance of these organisms were lower around the bridge construction area (BC and UC) compared to stations further away. This implies the impact of bridge construction activities on the phytoplankton and epipelic algae of the study area.

Open Access: This is an open access article distributed under the terms of the Creative Commons Attribution 4.0 License, which permits unrestricted use, distribution, and reproduction in any medium, provided the original author(s) if the sources are credited.

\section{REFERENCES}

APHA. (2012). Standard methods for the examination of water and waste water, American Public Health Association (APHA). Washington, DC, pp. 2462.

Angermeier, P.L. and Rosenberger, A.E. (2005). Impacts of new highways and subsequent landscape urbanization on stream habitat and biota. Reviews in Fisheries Science, 13(3): 141-164.

Borowitzka, M.A., Lethbridge R.C., Lorna, C. (1990). Species richness, spatial distribution and colonisation pattern of algal and invertebrate epiphytes on the sea grass, Amphibolis griffithii. Marine Ecology, 64: 281-291.

Chindah, A.C. (2004). Response of periphyton community to salinity gradient in tropical estuary, Niger Delta. Polish Journal of Ecology, 52: 83-89.

Chindah, A.C. and Nduaguibe, U. (2003). Farm waste water on the water quality of lower Bonny River, Niger Delta, Nigeria. Environment and Society, 1(2): 206-222.

Chindah, A.C. and Pudo, J. (1991). A preliminary checklist of algae found in plankton of Bonny River in Niger Delta, Nigeria. Fragmenta Floristica et Geobotanica., 36: 112-126

Erondu, E.S. and Chindah, A.C. (1991). Physico-chemical and phytoplankton changes in a tidal freshwater station of the New Calabar River South Eastern Nigeria. Environmental Ecology, 9:561-570.
Farkas A., Salanki J., Specziar, A. and Varanka, I. (2001). Metal pollution as health indicator of lake ecosystems. International Journal of Occupational Medical and Environmental. Health, 14(2): 163-170.

Giberto, D.A., Bremec, C.S., Acha, E.M. and Mianzan, H. (2004). Large-scale spatial patterns of benthic assemblages in the SW Atlantic: The Riodela Plata estuary and adjacent shelf waters. Estuarine and Coastal Shelf Science, 61: 1-13.

Harding Jr. L.W., Mallonee, M.E. and Perry, E.S. (2002). Toward a predictive understanding of primary productivity in a temperate, partially stratified estuary. Estuarine and Coastal Shelf Science, 55: 437-463, https://doi.org/10.1006/ecss.

Hedrick, L.B., Welsh, S.A., Anderson, J.T., Lin, L.S., Chen, Y. and Wei, X. (2010). Response of benthic macroinvertebrate communities to highway construction in an Appalachian watershed. Hydrobiologia, 641(1): 115-131.

Jackson, S. (2003). Ecological considerations in the design of river and stream crossings. Proceedings of the International Conference on Ecology and Transportation (eds C.L. Irwin, P. Garrett \& K.P).

Kadiri, M.O., (2000). Phytoplankton distribution in some coastal waters of Nigeria. Nigerian Journal of Botany, 12(1): 51 -62.

Kara, H. and Sahin, B. (2000). Epipelic and epilithic algae of Degirmendere River (Trabzon-Turkey). Turkish Journal of Botany, 25: 177-186.

Manoj, K. and Bhavesh, C. (2008). Evaluation of Benthic Communities in the intertidal region of Tapi Estuary, Surat, Gujarat. Indian Hydrobiology, 11(1): 69-77.

Mishra, P.K., Mishra, S., Selvakuma, G., Bisht, R.S.C., Kundu S., Bisht J.K. and Gupta H.S. (2008). Characterization of a psychrotrophic plant growth promoting pseudomonaspgers17 (mtcc9000) isolated from north western Indian Himalayas. Annals of Microbiology, 58 (4): 1-8.

Murugan, T. (2008). An Inventory of the algal flora of temple tanks at Kanchipuram. Indian Hydrobiology, 11(1):99-102

Nair, P.V.R., Joseph, K.J., Balachandan, V.K. and Pillai, V.K. (1981). A study on primary production in Vembanad Lake. Bulletin Department of Marine Sciences Cochin University 7(1):161 -170.

Nwadiaro, C.S. (1990). A hydrobiological survey of the Chanomi creek system, lower Niger Delta, Nigeria. Limnological (Berlin), 21: 263-274.

Nwankwo, D.I., Adesalu, T.A., Olabode, R.J., Osiegbu G.O. and Owoseni, T.I. (2003). Additions to a preliminary check-list of planktonic algae in Lagos Lagoon, Nigeria. Journal of Science, Technology and Environment, 3(1-2): 8-12.

Ogamba, E.N., Chindah, A.C., Ekweozor, I.K.E. and Onwuteaka, J.N. (2004). Water quality and phytoplankton in Elechi creek complex of the Niger Delta. Journal of Nigeria of Environment Society, 2(2):121-130.

Polge, N., Sukatar, A., Soylu, E.N. and Gönülol, A. (2010). Epipelic algal flora in the Küçükçekmece Lagoon. Turkish Journal of Fisheries and Aquatic Sciences 10: 39-45 (2010). https:// doi.org/10.4194/trjfas.2010.0106

Portner, H. O. and Farell, A. P. (2008). Physiology and climate 
change. Science, 322(5902) 690-692. https:// doi.org/10.1126/science.1163156

Prasad, R. and Singh, R.N. (1996). Effect of feeding water soaked corn and fodder on performance and digestibility of nutrients in Angora rabbits. Indian Journal of Animal. Nutrition, 13(3): 162-166.

Rennie, M.D. and Jackson, L.J. (2005). The influence of habitat complexity on littoral invertebrate distributions: Pattern differs in shallow prairie lake with and without fish. Canadian Journal of fisheries and Aquatic Science, 62: 2088-2099.

Roni, P., Beechie, T.J., Bilby, R.E., Leonetti, F.E., Pollock, M.M. and Pess, G.R. (2002). A review of stream restoration techniques and a hierarchical strategy for prioritizing restoration in Pacific Northwest watersheds. North American Journal of Fisheries Management, 22(1): 1-20.

Ruediger, B. (2001). High, wide, and handsome: designing more effective wildlife and fish crossings for roads and highways. In: Proceedings of the 2001 International Conference on Ecology and Transportation, 24-28 September 2001. Centre for Transportation and the Environment, North Carolina State University. pp. 509-516.
Sagar, J.P., Olson, D.H., Schmitz, R.A. and Beaupre, S. (2004). Survival and growth of larval coastal giant salamanders (Dicamptodon tenebrosus) in streams in the Oregon Coast Range. Copeia, 1: 123-130.

Townsend, D.M., Cammen, L.b., Holligan, P.H., Camphell, D.E. and Pettigrew, N.R. (1994a). Causes and consequences of variability in the timing of spring phytoplankton blooms. Deep Sea Research, 41:747-765.

Townsend, D.M., Keller, M.D., Sieracki, M.E. and Ackleson, S.G. (1992b). Spring phytoplankton blooms in the absence of vertical water column stratification. Nature, 360: 56-62

Traunspurger, W. and Drew, C. (1996). Toxicity analysis of freshwater and marine sediments with meio and macrobenthic organisms: a review. Hydrobiologia, 328: 215261,

Verma, R. (2002). Role of Rpn11 metalloprotease in deubiquitination and degradation by the $26 \mathrm{~S}$ proteasome. Science, 298(5593):611-5.

Wickstead, J.H. (1976). Marine Zooplankton (Studies in Biology) Published by Hodder (1976). ISBN 10: 0713125497 ISBN 13: 9780713125498 